\title{
Phylogenetic and Chemical Analyses of Cirsium pendulum and Cirsium setidens Inhabiting Korea
}

\author{
Sun Kyun Yoo and Young-Min Bae ${ }^{2}$ * \\ ${ }^{1}$ Department of Food Science and Biotechnology, Joongbu University, Geumsan 312-702, Korea \\ ${ }^{2}$ Department of Microbiology, Changwon National University, Changwon 641-773, Korea
}

Received July 9, 2012 /Revised August 14, 2012 /Accepted August 16, 2012

\begin{abstract}
Cirsium pendulum plants were collected from Hongcheon, Pyeongchang, Wonju, Yangyang in Kangwondo, Gapyeong in Gyeongkido, and Choongju in Choongcheongbukdo. Cirsium setidens plants were collected from Taebaek in Kangwondo and Bonghwa in Kyeongsangbukdo. Genomic DNA was prepared from those plants and used for the amplification of $18 \mathrm{~S}$ rDNA, ITS1, 5.8S rDNA, ITS2, and part of $28 \mathrm{~S}$ rDNA. The PCR products were sequenced, and the sequence was deposited in the GenBank. The comparison of those sequences has revealed that the rDNA sequences are identical for all six $C$. pendulum plants, but that the ITS1 and ITS2 sequences contain variable nucleotides. The two $C$. setidens plants had different nucleotides in $18 \mathrm{~S}$ rDNA, ITS1, and ITS2. The comparison of the DNA sequences of $C$. pendulum and $C$. setidens collected in this study with $C$. pendulum of Hokkaido in Japan and $C$. japonicum of Anhui in China indicated that the plants of those three species are clearly divided into three distinct groups. The silymarin content of the collected plants was analyzed and turned out to be quite high. Therefore, it has been found that both $C$. pendulum and $C$. setidens plants are producing large amounts of silymarin, which has been reported to have various medicinal effects.
\end{abstract}

Key words : Thistle, Cirsium pendulum, Cirsium setidens, phylogenetic analysis, silymarin

\section{서 론}

영어로 'thistle'는 우리말로 엉겅퀴라고 번역이 되는데, 사 실 이 단어의 정확한 정의에는 약간의 혼선이 있다. 즉, thistle 은 국화과(Asteraceae 또는 Compositae) 식물들 중에서 날카 로운 가시를 가진 식물들을 일반적으로 지칭하는 말인데, 이 단어가 좁은 의미로 사용될 경우에는 국화과 엉겅퀴아족(tribe Carduinae)에 속하는 Carduus, Cirsium 및 Onopordum 속의 식 물들만을 지칭하지만, 넓은 의미로 사용될 경우에는 엉겅퀴아 족의 식물들 이외에도 국화과에 속하는 Arctium, Carlina, Centaurea, Cicerbita, Cnicus, Cynara, Echinops, Notobasis, Scolymus, Silybum, Sonchus 속의 식물들을 함께 지칭하기도 한다[6]. 우리나라에서는 통상 엉겅퀴 아족에 속하는 식물들을 모두 엉겅퀴라고 부르기도 하지만, 구체적인 종(species)을 지 칭할 때에는 Cirsium japonicum 종에 속하는 식물을 엉겅퀴라 고 하고 나머지 종들을 다른 이름으로 부르기도 한다. 따라서 본 논문에서는 혼선을 피하기 위해서 C. japonicum 종의 식물 들만을 엉겅퀴로 지칭하기로 한다.

국화과의 엉겅퀴족(Cardueae)에는 대략 83속 2,500여 종 의 식물들이 포함되어 있는데, 이중에서도 36속 1,600여 종 의 식물들이 다시 엉겅퀴 아족(Carduinae)으로 분류되고 있

*Corresponding author Tel : +82-55-213-3483, Fax : +82-55-213-3480

E-mail : yominbae@changwon.ac.kr
다. 엉겅퀴 아족 중에서는 Carduus 속(약 90여 종), Cirsium 속(200-300여 종) 그리고 Onopordum 속(약 60여 종)이 큰 분 류군으로 되어 있다[6]. 국내에 자생하는 엉겅퀴의 종에 대 해서는 많은 논란이 있어왔으나, 최근에 정리된 바에 의하 면 한국산 엉겅퀴들 중에서 Cirsium 속에 속하는 것들로는 Cirsium japonicum(엉겅퀴)을 비롯하여 C. pendulum(큰엉겅 퀴), C. setidens(고려엉겅퀴), C. rhinoceros(바늘엉겅퀴), $C$. schantarense(도깨비엉겅퀴), $C$. lineare(버들잎엉겅퀴), $C$. vlassovianum(흰잎엉겅퀴), C. nipponicum(물엉겅퀴)의 8종이 자생하고 있는 것으로 보고되었다[16]. 그러나 제주도에 자 생하는 바늘엉겅퀴와 울릉도에 자생하는 물엉겅퀴를 제외 하고는 국내에 자생하는 Cirsium 속 식물들의 분포에 대해 서는 체계적으로 연구된 적이 없고, 이러한 식물들의 분류 또한 전적으로 형태에 의존하고 있기 때문에 분자유전학적 (molecular phylogenetic) 자료는 전혀 알려져 있지 않다. GenBank의 자료를 찾아보아도 전 세계적으로 중국의 안휘 성에서 채집된 C. japonicum 한 종류(accession EU592014)와 일본의 홋카이도에서 채집된 C. pendulum 한 종류(accession $\mathrm{AB} 035977, \mathrm{AB} 035998)$ 의 ITS1 및 ITS2의 염기서열이 등록되 어 있을 뿐, 그 외의 지역에서 자생 중인 C. japonicum 종 또 는 C. pendulum 종 식물들의 경우에는 ITS1 또는 ITS2의 염 기서열이 보고되어 있는 경우가 전혀 없다.

국내 자생종들 중에서 큰엉겅퀴(Cirsium pendulum Fisch)는 대한식물도감에 의하면 우리나라의 낮은 지대에서 자라는 다 년초로서 높이 1 2 $\mathrm{m}$ 이고, 세로줄이 있으며 윗부분에서 가지 
가 갈라지고 거미줄 같은 털이 있다고 알려져 있을 뿐, 그 분포 에 대해서는 명확하게 설명이 되어 있지 않다[12].

강원도 지역에서 “곤드레"라는 귀한 나물로 알려져 있는 고려엉겅퀴(Cirsium setidens Nakai) 역시 산야에서 자라는 다 년초로서 높이가 $1 \mathrm{~m}$ 에 달하고 뿌리가 곧으며 가지가 사방으 로 퍼지는 것으로 알려져 있을 뿐, 그 분포에 대해서는 설명이 없다[12]. 고려엉겅퀴의 ITS1이나 ITS2의 염기서열은 GenBank에 아직까지 보고된 적이 없다.

이러한 식물들의 국내 분포에 대해서도 특정 지역에서 국지 적으로 발견되었다는 보고는 있으나, 전국적 분포에 대해서 체계적인 설명을 제공하는 자료는 발견할 수 없었다 $[3,13,14,18,19]$. 따라서 본 연구에서는 국내에 자생하는 큰엉겅 퀴와 고려엉겅퀴의 분포에 대한 연구를 시도해 보았다. 그 결 과, 강원도의 홍천, 평창, 원주, 양양과 강원도에 인접한 경기 도 가평, 충청북도 충주에서 큰엉겅퀴를 채집할 수 있었다. 또한 강원도 태백시와 이에 인접한 경상북도 봉화에서는 고려 엉겅퀴를 채집할 수 있었다(Table 1). 본 연구에서는 이렇게 채 집된 큰엉겅퀴와 고려엉겅퀴들의 정확한 동정(identification) 및 분자유전학적 분석을 위해서 $18 \mathrm{~S} \mathrm{rDNA}$, ITS1, $5.8 \mathrm{SDNA}$, ITS2의 전부 및 $28 \mathrm{~S} \mathrm{rDNA}$ 의 일부 염기서열을 밝혀서 서로 비교해 보았다.

엉겅퀴의 뿌리를 건조한 것을 대계라고 하는 데, 우리나라 에서 옛날부터 한약재로 사용되어 왔다. 외국에서는 엉겅퀴 중의 하나인 milk thistle (Silybum marianum)의 추출물이 여러 가지 약리 활성을 가진다는 것이 오래 전부터 알려져 왔기 때문에 이 엉겅퀴에 연구가 집중되어 왔다[9]. 결국, 이 엉겅퀴 에서 silymarin이라는 물질이 발견이 되었는데, 이 물질이 항 암활성, 항바이러스 활성, 항산화 활성 및 당뇨증상 완화, 방사 선 및 자외선에 의한 손상까지도 완화시켜 주는 활성을 가지 는 것으로 보고되고 있다 $[1,5,7,8,10,15]$. 엉겅퀴 추출물의 항미 생물 활성에 대해서도 보고된 적이 있는데, silymarin 중에서 silybin이 Bacillus subtilis와 Staphylococcus epidermidis와 같은 그람(Gram) 양성 세균에 대해서 강력한 증식억제능이 있다는 보고가 있었고[11], 지느러미엉겅퀴의 추출물이 역시 그람 양 성 세균인 Mycobacterium fortuitum과 Mycobacterium smegmatis에 대한 증식억제능이 있다는 보고가 있었다[2]. 따라서 본 연구에서는 큰엉겅퀴 및 고려엉겅퀴에서도 silymarin이 존재 하는 지를 시험하기 위해서 화학적 분석도 수행하였다.

\section{재료 및 방법}

\section{탐색 대상 식물의 수집}

본 연구에 사용할 큰엉겅퀴와 고려엉겅퀴를 여러 지점에서 채집하였다. 큰엉겅퀴와 고려엉겅퀴가 발견되면 사진을 촬영 하고 잎을 채취하였다.

\section{Extraction and analysis of silymarin}

수집된 식물들을 음건한 후, 건조된 잎 $0.1 \mathrm{~g}$ 을 microfuge tube에 넣고, spatular를 이용하여 잘게 분쇄하였다. 여기에 메탄올 $0.5 \mathrm{ml}$ 을 첨가하고 $40^{\circ} \mathrm{C}$ 에서 24 시간 동안 유지시켰다. 이것을 $20,000 \times g$ 에서 10 분간 원심분리 하였다. 이렇게 준비된 추출액 $10 \mu 1$ 를 Waters $1525 \mathrm{HPLC}$ 에 주입하고, Waters 2487 dual wavelength absorbance detector로 분석하였다. Separation에 사용된 용매로는 acetonitrile과 water (1:1)를 사 용하였고 flow rate는 $1 \mathrm{ml} / \mathrm{min}$ 로 하였다. 분석에 사용된 column은 Sunfire column $4.6 \times 150 \mathrm{~mm}$ 으로서 column의 온도는 $40^{\circ} \mathrm{C}$ 로 유지시켰고, 파장 $288 \mathrm{~nm}$ 에서 absorbance peak들을 확인하여 silymarin의 존재여부를 확인하였다.

Purification of genomic DNA and polymerase chain reaction

Genomic DNA는 QIAGEN의 DNeasy Plant Mini Kit를 사용하여 건조된 잎으로부터 추출되었다. PCR 반응을 위해 서는 DNA template $200 \mathrm{ng}$, forward primer $2.5 \mathrm{pmol}$, reverse primer $2.5 \mathrm{pmol}$, dNTPs mixture $2 \mu \mathrm{l}(10 \mathrm{nM}$ each) 그리고 Pfu DNA polymerase $2 \mu \mathrm{l}(6 \mathrm{U})$ 를 포함하는 $100 \mu \mathrm{l}$ 의 반응액에서 반응을 진행하였다. PCR 반응에 사용된 forward primer 및 reverse primer는 Table 2에 표시하였다. 반응조건은 $94^{\circ} \mathrm{C}$ 에서 2 분간 한 cycle, 그리고 $94^{\circ} \mathrm{C}$ 에서 1 분, $59^{\circ} \mathrm{C}$ 에서 1 분, $72^{\circ} \mathrm{C}$ 에서 5 분씩 $30 \mathrm{cycle}$ 을 진행시킨 후, 최 종적으로 $72^{\circ} \mathrm{C}$ 에서 10 분간 유지시켰다. 이때에 사용된 forward primer는 $18 \mathrm{~S}$ rDNA의 $5^{\prime}$-ends의 conserved region을 target으로 하여 제조되었다. 이때에 식물들의 $18 \mathrm{~S} \mathrm{rDNA}$ 에 서 존재하지 않는 제한효소 $B g I \Pi$ 의 인식부위를 forward primer의 $5^{\prime}$-말단에 첨가하여서 cloning시에 사용할 수 있 도록 하였다. Reverse primer는 $28 \mathrm{~S} \mathrm{rDNA}$ 의 $5^{\prime}$ 부위를 target으로 하여 제조하였다. PCR에는 error가 많이 발생하 는 Taq DNA polymerase 대신에 error가 훨씬 적게 발생하 는 Pfu DNA polymerase를 사용함으로써 반응 중에 DNA sequence가 변경되는 것을 최소화하였다.

Table 1. Locations where $C$. pendulum and $C$. setidens plants have been collected

\begin{tabular}{ll}
\hline Thistles & Places obtained \\
\hline C. pendulum $\mathrm{CJ}$ & Choongcheongbukdo Choongju \\
C. pendulum $\mathrm{GP}$ & Gyeongkido Gapyeong \\
C. pendulum $\mathrm{HC}$ & Kangwondo Hongcheon \\
C. pendulum $\mathrm{PC}$ & Kangwondo Pyeongchang \\
C. pendulum $\mathrm{WJ}$ & Kangwondo Wonju \\
C. pendulum $\mathrm{YY}$ & Kangwondo Yangyang \\
C. setidens $\mathrm{TB}$ & Kangwondo Taebaek \\
C. setidens $\mathrm{BH}$ & Kyeongsangbukdo Bonghwa \\
\hline
\end{tabular}




\section{Cloning of the PCR products and DNA sequencing}

PCR products는 agarose gel에서 분자량에 따라 separation 시킨 후, 예상되는 크기의 DNA를 surgical blade로 잘라내고, Promega의 Gel and PCR purification system을 사용하여 gel slice로부터 DNA를 정제 하였다. 이렇게 정제된 PCR product 는 Sma I 으로 절단된 pBluscript II SK'와 섞어서 ligation 시 키고, E. coli $\mathrm{DH} 5 a$ 에 transformation 하였다. 이러한 transformants를 $100 \mathrm{\mu g} / \mathrm{ml}$ 의 ampicillin을 함유하는 MacConkey agar에 도말하고 $37^{\circ} \mathrm{C}$ 에서 배양하였다. 흰색 colony들을 selection하여서 이들로부터 plasmid DNA를 추출한 후에, supercoiled plasmid DNA 및 $P_{v} u \Pi$ 로 절단된 plasmid DNA를 agarose gel electrophoresis로 분석하였다. 그 결과, 예상되는 크기의 PCR 산물이 얻어졌으므로 이러한 DNA들의 염기서열 분석을 (주)솔젠트에 의뢰하였다.

Sequence alignment and phylogenetic analyses

큰엉겅퀴 6가지와 고려엉겅퀴 2가지의 $18 \mathrm{~S} \mathrm{rDNA}, \mathrm{ITS} 1$, $5.8 \mathrm{~S} \mathrm{rDNA}$, ITS2 및 $28 \mathrm{~S} \mathrm{rDNA}$ 의 일부를 포함하는 $\mathrm{DNA}$ 의 염기서열을 밝히고, ClustalW 1.83을 사용하여 서로 align 하 였다[4]. 이렇게 align된 염기서열 중에서 ITS1과 ITS2 염기서 열은 MEGA5.0을 사용하여 neighbor-joining tree를 만드는 데 에 사용되었다[17].

\section{결과 및 고찰}

\section{큰엉겅퀴와 고려엉겅퀴의 형태적 분석 및 서식처}

국내의 여러 지역을 직접 답사하여 큰엉겅퀴와 고려엉겅퀴 를 수집하였다. 이렇게 수집된 식물들을 형태에 따라 분류해 본 결과, Table 1에 나타낸 바와 같이 C. pendulum 6개체 및 C. setidens 2 개체가 채집되었다. 특히 큰엉겅퀴는 강원도에서 는 홍천, 원주, 평창, 양양의 4 개 지점에서 채집되었고, 강원도 에 인접한 경기도 가평과 충청북도 충주에서도 채집되었다. 그리고 강원도에서도 태백시에서는 고려엉겅퀴가 채집되었 고, 태백시에 인접한 경상북도 봉화에서도 고려엉겅퀴를 채집 할 수 있었다. 그러나 경기도 용인 및 기타 남부지방에서는 엉겅퀴( $C$. japonicum)는 발견할 수 있었으나 큰엉겅퀴나 고려 엉겅퀴는 발견할 수 없었다. 또한 한 지역에서 이들 3 종의 엉 겅퀴 중에서 2종 이상이 동시에 관찰되는 경우는 없었다. 그러 나 다른 연구자들에 의하면 한 지역에서 2종 이상의 Cirsium 속 식물들이 동시에 관찰되는 경우가 있었다[14]. 또한 본 연구 에서는 큰엉겅퀴가 강원도 및 그 인접지역에서만 관찰되었으 나, 전북 부안군 하서면 청호리에 소재하는 석불산에서도 큰 엉겅퀴가 관찰되었다는 보고가 있었다[3]. 그러나 인접한 지역 인 전북 완주군 고산면 오산리 소재의 고산 자연 휴양림에서 는 엉겅퀴와 지느러미엉겅퀴는 관찰되었으나, 큰엉겅퀴는 관 찰되지 않았고[14], 전남 영암군과 강진군에 걸쳐있는 월출산
국립공원에서는 도깨비엉겅퀴만이 관찰되었다고 보고되었다 [13]. 다른 Girsium 속 식물들은 꽃이 하늘을 향하고 있는 반면 에, 큰엉겅퀴와 도깨비엉겅퀴는 모두 꽃이 아래를 향하고 있 기 때문에 이 두 종은 숙은엉겅퀴라고도 한다. 따라서 꽃만 가지고 판단하면 이 두 종은 서로 혼동되는 경우가 많은데, 실제로 야생화 동호인들의 인터넷 사이트에서는 이 두 종이 같은 식물의 다른 이름이라고 설명이 되어 있는 경우도 많다. 따라서 이 두 종은 구분이 쉽지 않기 때문에 전적으로 형태에 만 의존한 분류는 오류가 발생할 가능성을 배제할 수 없다. 고려엉겅퀴의 경우에는 충북 제천시 백운면 덕동리에서 관 찰되었다는 보고가 있고, 또한 충북 괴산군 장연면과 감물면 에 걸쳐있는 박달산에서도 관찰되었다는 보고가 있다[17,18]. 따라서 현재까지 밝혀진 이 종의 서식처는 강원도 태백부터 경북 봉화 그리고 충북의 제천을 거쳐 괴산까지 이어지고 있 다고 할 수 있다.

\section{큰엉겅퀴와 고려엉겅퀴의 계통분류학적 분석}

채집된 엉겅퀴들의 형태에 의한 동정을 위해서는 잎, 꽃, 화서, 총포 등의 기관별 형태학적 특징들에 대해서 식물도감 및 논문을 참고하였다[12,16]. 계통분류학적 분석을 위해서는 수집된 식물들의 genomic DNA를 추출하고, 이를 template로 하는 $\mathrm{PCR}$ 을 수행하여 $18 \mathrm{~S} \mathrm{rDNA}$, internal transcribed spacer (ITS) $1,5.8 \mathrm{~S}$ rDNA 및 ITS2의 염기서열을 밝혔다. PCR에 사용 된 primers는 $18 \mathrm{~S} \mathrm{rDNA}, \mathrm{ITS1}, 5.8 \mathrm{~S} \mathrm{rDNA}$, ITS2의 전부, 그리 고 $26 \mathrm{~S} \mathrm{rDNA}$ 의 일부를 증폭할 수 있도록 고안하여 사용하였 다(Table 2). 이 경우에 예상되는 PCR 산물의 크기는 대략 2.5-kb 정도로 추정되는데, 실제로 그러한 크기의 PCR 산물이 관찰되었다.

Table 1에 나열된 식물들의 $18 \mathrm{~S}$ rDNA, ITS1, 5.8S rDNA, ITS2 및 $28 \mathrm{SDNA}$ 를 증폭하여 그 염기서열을 분석하고, 그 결과를 GenBank에 등록하였다(accession numbers JX274255, JX274256, JX274257, JX274258, JX274259, JX274260). 염기서열 분석 결과, 큰엉겅퀴들의 $\mathrm{PCR}$ 산물은 모두 그 길이가 2,509-bp 였으나, 고려엉겅퀴들은 모두 2,513-bp였다. 염기서열을 서로 비교해 본 결과, 고려엉겅퀴들이 ITS1에서 1-bp, 그리고 ITS2 에서 3-bp의 염기를 더 가지고 있었다(Fig. 1). 큰엉겅퀴의 경 우에는 모두 $185 \mathrm{rDNA}, 5.8 \mathrm{~S} \mathrm{rNA}$ 및 $28 \mathrm{~S} \mathrm{rDNA}$ 부분에서는 그 염기서열이 서로 완전히 같았다. 그리고 가평, 원주, 양양에 서 채취된 큰엉겅퀴들의 경우에는 증폭된 염기서열이 ITS1 및 ITS2까지 포함한 모든 부위에서 서로 완전히 같았다. 따라 서 이 세 가지 식물의 경우에는 가평 큰엉겅퀴의 염기서열만

Table 2. Primers used in this study

\begin{tabular}{ll}
\hline Primers & Sequences \\
\hline Forward & 5'-TTTAGATCTGGTTGATCCTGCCAGT-3' \\
Reverse & 5'-TCCTCCGCTTATTGATATGC-3' \\
\hline
\end{tabular}


A

\begin{tabular}{lr} 
Choongju & 1853 1859 \\
Gapyeong & CGG-TGT \\
Hongcheon & CGG-TGT \\
Pyeongchang & CGG-TGT \\
Hokkaido & CGG-TGT \\
Anhui & CGG-TGT \\
Taebaek & CGG-TGT \\
Bonghwa & CGGGCGT \\
\hline & CGGGCGT
\end{tabular}

B

$\begin{array}{lr}\text { Choongju } & 2268 \\ \text { Gapyeong } & \text { GTT---CGT } \\ \text { Hongcheon } & \text { GTT---CGT } \\ \text { Pyeongchang } & \text { GTT---CGT } \\ \text { Hokkaido } & \text { GTT---CGT } \\ \text { Anhui } & \text { GTT---CGT } \\ \text { Taebaek } & \text { GTT---CGT } \\ \text { Bonghwa } & \text { GTTGTTCGT } \\ & \text { GTTGTTTGT }\end{array}$

Fig. 1. Alignment of ITS sequences of $C$. pendulum and $C$. setidens. Only part of the alignment is shown. Numbers above the sequence indicate the position of nucleotides of $C$. setidens Taebaek as deposited to the GenBank (accession JX274259).

Table 3. Variable sites in the ITS sequences of $C$. pendulum plants

\begin{tabular}{|c|c|c|c|c|}
\hline \multirow{3}{*}{ Plants } & \multicolumn{4}{|c|}{ Position of nucleotides } \\
\hline & \multicolumn{2}{|c|}{ ITS1 } & \multicolumn{2}{|c|}{ ITS2 } \\
\hline & 26 & 46 & 106 & 117 \\
\hline Gapyeong & $\mathrm{C}$ & $\mathrm{T}$ & $\mathrm{T}$ & $\mathrm{C}$ \\
\hline Hongcheon & $\mathrm{T}$ & $\mathrm{T}$ & $\mathrm{T}$ & $\mathrm{C}$ \\
\hline Hokkaido & $\mathrm{C}$ & $\mathrm{T}$ & $\mathrm{C}$ & $\mathrm{C}$ \\
\hline Choongju & $\mathrm{C}$ & $\mathrm{C}$ & $\mathrm{T}$ & $\mathrm{C}$ \\
\hline Pyeongchang & $\mathrm{C}$ & $\mathrm{C}$ & $\mathrm{C}$ & $\mathrm{T}$ \\
\hline
\end{tabular}

GenBank에 등록하였다.

Table 3을 보면 가평 큰엉겅퀴를 기준으로 하였을 때, 홍천, 충주 및 홋카이도 큰엉겅퀴는 각각 다른 부위에서 한 염기씩 달랐다. 다만 평창 큰엉겅퀴만이 ITS1에서 한 부위 그리고 ITS2에서 두 부위가 가평 큰엉겅퀴와 달랐다. 그리고 한 가지 더 주의를 끄는 것은 서로 다른 염기가 존재하는 모든 부위가 pyrimidine이라는 점이다. 따라서 돌연변이에 의해 염기서열
이 바뀌었다고 해도 모두 transition에 그쳤고, transversion은 일어나지 않았다는 것을 보여주고 있다. 따라서 일본 홋카이 도의 큰엉겅퀴를 포함해서 이들 큰엉겅퀴들 간의 분화는 비교 적 최근에 발생했다는 것을 알 수 있다.

Table 4 에서는 고려엉겅퀴들의 염기서열을 비교한 결과를 나타내었는데, 큰엉겅퀴의 경우와는 달리 고려엉겅퀴들의 경 우에는 $18 \mathrm{~S} \mathrm{rDNA}$ 에서 2 군데, ITS1에서 3군데 그리고 ITS2에 서는 무려 5 군데에서 차이를 나타냈다. 또한 이 경우에는 transition과 transversion이 모두 나타난다. 비록 소백산맥에 의해서 서로 분리가 되었다고는 하지만 태백 고려엉겅퀴와 봉화 고려엉겅퀴를 채취한 지점은 직선거리로 $12 \mathrm{~km}$ 정도 밖 에 떨어져 있지 않다. 따라서 고려엉겅퀴의 서식지가 돌연변 이 유발물질의 농도가 특별히 높거나 하지 않는다면 고려엉겅 퀴는 큰엉겅퀴에 비해서 독립된 종으로 분화한 지 대단히 오 랜 시간이 지났다는 것을 알 수 있다.

가평, 홍천, 충주, 평창 그리고 일본 홋카이도 큰엉겅퀴, 중 국의 안휘성에서 채취된 엉겅퀴(C. japonicum) 및 태백, 봉화

A
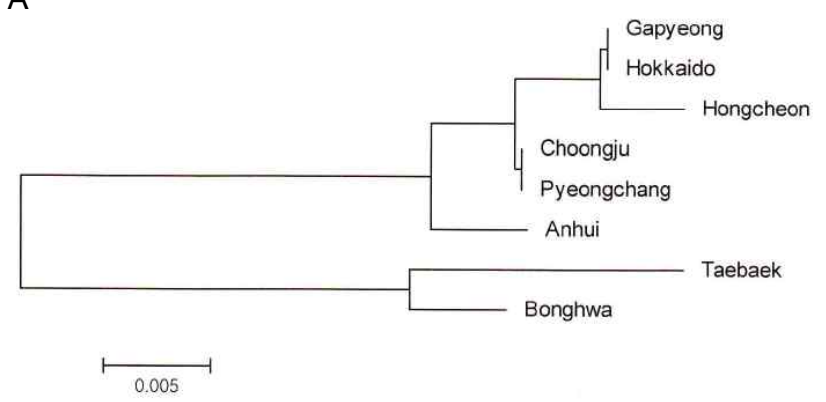

B

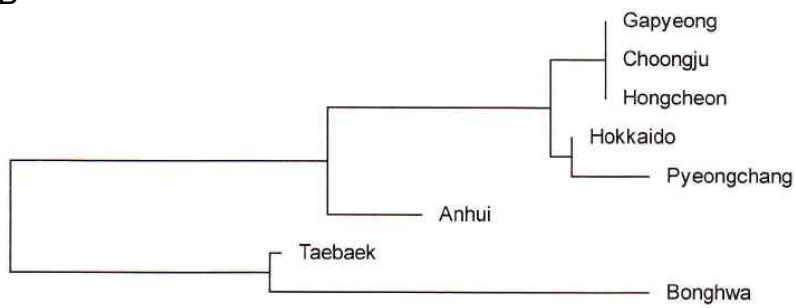

$\longmapsto_{0.005}$

Fig. 2. Neighbor-joining tree of ITS sequences of $C$. pendulum, $C$. japonicum and $C$. setidens. A, Trees constructed based on ITS1 sequences. B, Trees constructed based on ITS2 sequences.

Table 4. Variable sites in the $18 \mathrm{~S}$ rDNA, ITS1 and ITS2 sequences of $C$. setidens plants

\begin{tabular}{|c|c|c|c|c|c|c|c|c|c|c|}
\hline \multirow{3}{*}{ Plants } & \multicolumn{10}{|c|}{ Position of nucleotides } \\
\hline & \multicolumn{2}{|c|}{$18 \mathrm{~S}$} & \multicolumn{5}{|c|}{ ITS1 } & \multicolumn{3}{|c|}{ ITS2 } \\
\hline & 1297 & 1358 & 1835 & 1851 & 1954 & 2255 & 2274 & 2306 & 2347 & 2438 \\
\hline Taebaek & $\mathrm{T}$ & $\mathrm{A}$ & $\mathrm{C}$ & $\mathrm{T}$ & $\mathrm{C}$ & $\mathrm{C}$ & $\mathrm{C}$ & $\mathrm{T}$ & $\mathrm{C}$ & $\mathrm{C}$ \\
\hline Bonghwa & G & G & $\mathrm{T}$ & C & $\mathrm{T}$ & $\mathrm{T}$ & $\mathrm{T}$ & C & $\mathrm{T}$ & A \\
\hline
\end{tabular}


A

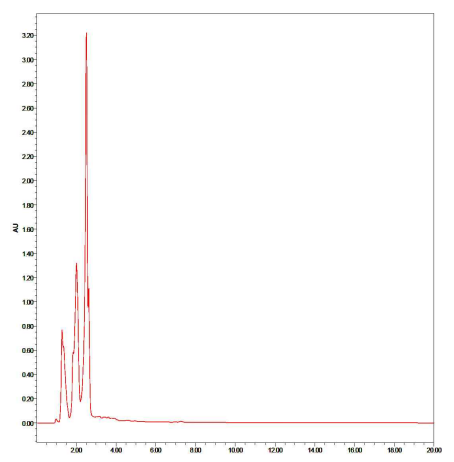

B

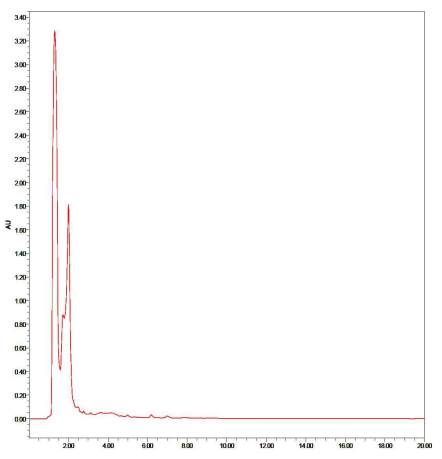

C

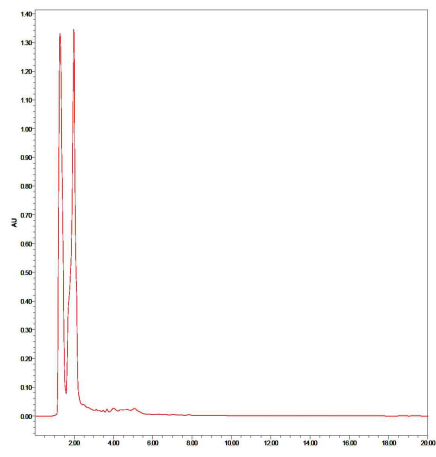

Fig. 3. HPLC profiles of the extract prepared from the selected thistles. A, Silymarin $2 \mathrm{mg} / \mathrm{ml}$; Extract of the $C$. pendulum from Gapyeong; C, Extract of the C. setidens from Taebaek.

고려엉겅퀴의 ITS1 및 ITS2 염기서열을 비교하여 neighbor-joining tree를 작성해 보았다(Fig. 2). 이러한 phylogenetic tree를 살펴보면, 비록 평창 큰엉겅퀴가 나머지 큰엉겅퀴들과 약간의 거리를 보여주더라도 여전히 큰엉겅퀴들은 엉겅퀴나 고려엉겅퀴와는 확연하게 구분되는 그룹에 같이 속한다는 것 을 알 수 있다. 또한 큰엉겅퀴들에 비해서 고려엉겅퀴들이 ITS1과 ITS2에서 각각 1-bp 및 3-bp가 더 긴데, 그 위치가 정확 히 일치하였다(Fig. 1). 홍천, 충주, 홋카이도의 큰엉겅퀴는 기 준 group과 한 곳에서 차이를 보이고 있는 반면에 평창 큰엉겅 퀴는 3 개의 위치에서 차이를 보이고 있다. 지리적으로 볼 때에 평창은 가평, 원주, 양양에 의해 둘러싸여 있다. 반면에 지리적 으로 멀리 떨어져있는 홋카이도의 엉겅퀴는 기준 그룹과 1 개 의 위치에서 밖에 차이를 보이지 않고 있다. 따라서 큰엉겅퀴 들의 ITS 염기서열은 서식처 간의 지리적 거리와는 별다른 상관관계를 가지고 있지 않는 것을 알 수 있다. 또한 홋카이도 의 큰엉겅퀴 보다 국내에 자생하는 큰 엉겅퀴들이 더 큰 다양 성을 보이고 있다는 점은 일본의 큰엉겅퀴가 한반도에서 유래 하였을 가능성을 암시해 주고 있다.

Table 4에서 나타나듯이 고려엉겅퀴의 경우에는 큰엉겅퀴 들보다 서로 간에 훨씬 더 큰 차이를 보이는 것을 알 수 있다. 그렇더라도 Fig. 1과 Fig. 2에서 볼 수 있듯이 이 식물들 역시 다른 종의 식물들과는 확연하게 구분되는 공통점을 서로 공유 하고 있는 것을 알 수 있다.

\section{Silymarin 분석}

현재까지 milk thistle에서 발견된 물질들 중에서 가장 주목 을 받고 있는 것은 silymarin인데, 이 silymarin의 존재 여부를 확인하고, 만일 존재한다면 그 함량을 분석하고 서로 비교하 기 위하여 채집된 큰엉겅퀴와 고려엉겅퀴들의 methanol 추출 물을 HPLC로 분석하였다. 이때에 Sigma-Aldrich로부터 구입 한 silymarin을 standard로 사용하였다. 그 결과, HPLC pro- file이 거의 모든 시료에서 서로 비슷하게 나타났기 때문에, Fig. 3에 가평 큰엉겅퀴와 태백 고려엉겅퀴의 HPLC profile을 나타내었다. Fig. 3에서 볼 수 있듯이 분석된 큰엉겅퀴 및 고려 엉겅퀴 추출물 모두에서 $2 \mathrm{mg} / \mathrm{ml}$ 보다 높은 농도의 silymarin 이 관찰 되었다. 따라서 건조된 잎에 함유된 silymarin이 완전 히 methanol에 추출이 되었다고 가정하더라도, 건조된 잎 0.1 $\mathrm{g}$ 당 $1 \mathrm{mg}$ 이상의 silymarin이 함유되어 있다고 볼 수 있다. 또한 비록 큰엉겅퀴와 고려엉겅퀴가 진화적으로는 이미 오래 전에 분기한 그룹들이지만 sylimarin 합성능은 여전히 공유하 고 있다는 것을 알 수 있다. Silymarin은 실제로 $\mathrm{C}_{25} \mathrm{H}_{22} \mathrm{O}_{10}$ 의 동일한 분자식을 갖는 silybin, isosilybin, silydianin 및 silychristin의 4 가지 isomer의 혼합물을 일컫는데, 이러한 silymarin의 효과에 대해서는 이미 많이 알려져 있다. 즉, Silymarin이 손상된 간의 회복을 돕고, 암세포의 증식을 억제 하고, 당뇨에도 효과가 있는 것으로 보고되어 왔으며, 그람 양성 세균에 대한 항미생물 활성도 있으며, 또한 최근에는 방 사선 및 자외선에 의한 피부 손상에도 효과가 있는 것으로 보고되고 있다[1,2,5,7,8,10,11,15].

\section{감사의 글}

본 연구는 산학협동재단의 2011년도 학술연구비 지원에 의해 수행되었으며 이에 감사드립니다.

\section{References}

1. Adhikari, M., Arora, R., Chawla, R., Sharma, J., Dhaker, A. S., Gupta, D., Dubey, N., Kumar, R., Ivanov, V., Gadjeva, V., Gevrenova, R. and Sharma, R. K. 2010. Evaluation of silymarin as a promising radioprotector. $Z$. Naturforsch $C$. 65, 337-346.

2. Bae, Y. M. 2010. Identification of a Carduus spp. showing anti-mycobacterial activity by DNA sequence analysis of its ITS1, 5.8S rRNA and ITS2. J. Life Sci. 20, 578-583. 
3. Beon, M. S. and Oh, H. K. 2007. Classification of community and distribution of vascular plants in the Mt. Seokbul. Korean J. Plant Res. 20, 375-382.

4. Chenna, R, Sugawara, H., Koike, T., Lopez, R., Gibson, T. J., Higgins, D. G. and Thompson, J. D. 2003. Multiple sequence alignment with the Clustal series of programs. Nucleic Acids Res. 31, 3497-3500.

5. Cheung, C. W., Gibbons, N., Johnson, D. W. and Nicol, D. L. 2010. Silibinin - A promising new treatment for cancer. Anticancer Agents Med Chem 10, 186-195.

6. Häffner, E. and Hellwig, F. H. 1999. Phylogeny of the tribe Cardueae (Compositae) with emphasis on the subtribe Carduinae an analysis based on ITS sequence data. Willdenowia. 29, 27-39.

7. Han, H. K., Je, H. S. and Kim, G. H. 2010. Effects of Cirsium japonicum powder on plasma glucose and lipid level in streptozotocin induced diabetic rats. Korean J. Food Sci. Technol. 42, 343-349.

8. Jeong, D. M., Jung, H. A. and Choi, J. S. 2008. Comparative antioxidant activity and HPLC profiles of some selected Korean thistles. Arch Pharm Res. 31, 28-33.

9. Kalantari, H., Shahshahan, Z., Hejazi, S. M., Ghafghazi, T. and Sebghatolahi, V. 2011. Effects of Silybum marianum on patients with chronic hepatitis C. J. Res. Med Sci. 16, 287-290.

10. Katiyar, S. K., Mantena, S. K. and Meeran, S. M. 2011. Silymarin protects epidermal keratinocytes from ultraviolet radiation-induced apoptosis and DNA damage by nucleotide excision repair mechanism. PLOS One. 6, e21410.

11. Lee, D. G., Kim, H. K., Park, Y. K., Park, S. C., Woo, E. R., Jeong, H. G. and Hahm, K. S. 2003. Gram-positive bac- teria specific properties of silybin derived from Silybum marianum Arch Pharm Res. 26, 597-600.

12. Lee, T. B. 2006. Coloured flora of Korea, 2nd eds.

13. Oh, H. K. and Beon, M. S. 2007. Flora and classification by characteristics of nature every second year in Wolchulsan national park. Korean J. Plant. Res. 20, 201-211.

14. Oh, H. K., Kim, Y. H. and Beon, M. S. 2006. Study on vascular plants of the Gosan Recreational Forest in Jeonbuk A case study of wild plants except planted plants. Korean J. Plant. Res. 19, 617-627.

15. Polyak, S. J., Morishima, C., Lohmann, V., Pal, S., Lee, D. Y., Liu, Y., Graf, T. N. and Oberlies, N. H. 2010. Identification of hepatoprotective flavonolignans from silymarin. Proc. Natl. Acad Sci. USA 107, 5995-5999.

16. Song, M. J. and Kim, H. 2007. Taxonomic study on Cirsium Miller (Asteraceae) in Korea based on external morphology. Korean J. Pl. Taxon. 37, 17-40.

17. Tamura, K., Peterson, D., Peterson, N., Stecher, G., Nei, M. and Kumar, S. 2011. MEGA5: Molecular evolutionary genetics analysis using maximum likelihood, evolutionary distance, and maximum parsimony methods. Mol. Biol. Evol. 28, 2731-2739.

18. You, J. H. 2005. The Vascular plants in construct-reserved site of ecological forest, Jecheon-si, Chungcheongbuk-do. Kor. J. Env. Eco. 19, 31-45.

19. You, J. H., Jin, Y. H., Jang, H. W., Cho, H. W., Lee, D. W., Yun, H. B. and Lee, C. H. 2004. The flora of Mt. Bakdal in Chungcheongbuk-do, Korea. Korean J. Plant Res. 17, 169-182.

\section{초록 : 국내에 자생하는 큰엉겅퀴와 고려엉겅퀴의 분자유전학적 및 화학적 분석 \\ 유선균 $^{1} \cdot$ 배영민 $^{2} \star$ \\ (중부대학교 식품생명과학과 · ${ }^{2}$ 창원대학교 미생물학과)}

국내에 자생 중인 큰엉겅퀴(Cirsium pendulum)를 강원도의 홍천, 원주, 평창, 양양 및 경기도 가평과 충청북도 의 충주에서 채취하고, 고려엉겅퀴(Cirsium setidens)를 강원도의 태백 및 경상북도의 봉화에서 채취하였다. 채취 된 식물들의 genomic DNA를 분리하여서 $18 \mathrm{~S} \mathrm{rDNA}$, ITS1, $5.8 \mathrm{~S} \mathrm{rDNA}$, ITS2 및 $28 \mathrm{~S} \mathrm{rDNA}$ 의 일부를 증폭하고, 그 염기서열을 분석하였다. 이렇게 얻어진 염기서열을 GenBank에 등록하고, 서로 비교해 보았다. 그 결과 큰엉겅 퀴는 6개체 모두에서 $18 \mathrm{~S} \mathrm{rDNA}$ 및 $5.8 \mathrm{~S} \mathrm{rDNA}$ 의 염기서열은 서로 완전히 일치하고 있으나, ITS1과 ITS2의 염기 서열에서는 약간의 차이를 보였다. 고려엉겅퀴의 경우에는 $18 \mathrm{~S} \mathrm{rDNA}$, ITS1 및 ITS2에서 2개체가 서로 비교적 큰 차이를 보였다. 일본의 홋카이도에서 채취된 큰엉겅퀴와 중국의 안휘성에서 채취된 엉겅퀴(Cirsium japanicum) 를 포함하여서 ITS1과 ITS2 염기서열을 비교한 결과, 엉겅퀴, 큰엉겅퀴, 고려엉겅퀴는 확연하게 서로 다른 그룹을 형성하는 것으로 나타났다. 또한 채취된 큰엉겅퀴 및 고려엉겅퀴들의 silymarin 함량을 분석해 본 결과, 모두에서 그 함량이 $2 \mathrm{mg} / \mathrm{ml}$ 가 넘는 것으로 나타났다. 따라서 엉겅퀴뿐만 아니라 큰엉겅퀴나 고려엉겅퀴도 여러 가지 약리작용을 가진 것으로 보고된 silymarin을 상당히 높은 농도로 함유하고 있는 것으로 나타났다. 